\title{
FORMULASI UNDANG-UNDANG NOMOR 1 TAHUN 1974 DALAM PERSINGGUNGAN ANTARA NEGARA DAN AGAMA
}

\author{
Fenni Febiana \\ Program Pascasarjana Magister Ilmu Agama Islam, Fakultas Ilmu Agama Islam \\ Universitas Islam Indonesia \\ Email: febiana1993@gmail.com
}

\section{Abstrak}

With the enactment of Law No. 1 of 1974 on Marriage, the authors noticed that the policy in question is to accommodate the aspirations of the majority Muslims who happen to choose schools of Shafi'i schools and realized in the form of legislation. The hope of course that the values of Islam, which had long color the way of arbitrate Indonesian people, then can have the firmness and recognition from the state. Thus the struggle of Muslims, which in certain portions require the enactment of Islamic law, at least one by one can be realized even with regard to the context Indonesian nation known multi-religious, ethnic and cultural. This is consistent with the theory put forward by the imam, al-Maliki al-mursalah mashlahah which can be translated "public interest". Al-maslahah occupy a very important position in determining the details of the general principles of the constitution in Islam. Through this principle all aspects of society that have not been regulated in the Quran and Sunnah Rasul can be arranged by the man, or the principles of a general nature contained in the Qur'an can be broken down further in order to determine a lot of applications in the life of society and the state extent not inconsistent with the spirit of Islamic law (sharia).

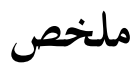

مع صدور القانون رقم ا لعام \ 19 ا المتعلق بالزواج، لاحظ الباحثون أن السياسة

في السؤال هو لاستيعاب تطلعات غالبية المسلمين الذين تحدث لاختيار المذهب الشافعي وأدركت في بحال التشريع .على أمل بالطبع أن القيم الإسامية التي كانت طويل اللون لطريقة القانون الإندونيسي، ثم يمكن أن يكون حزما واعترافا من الدولة. 


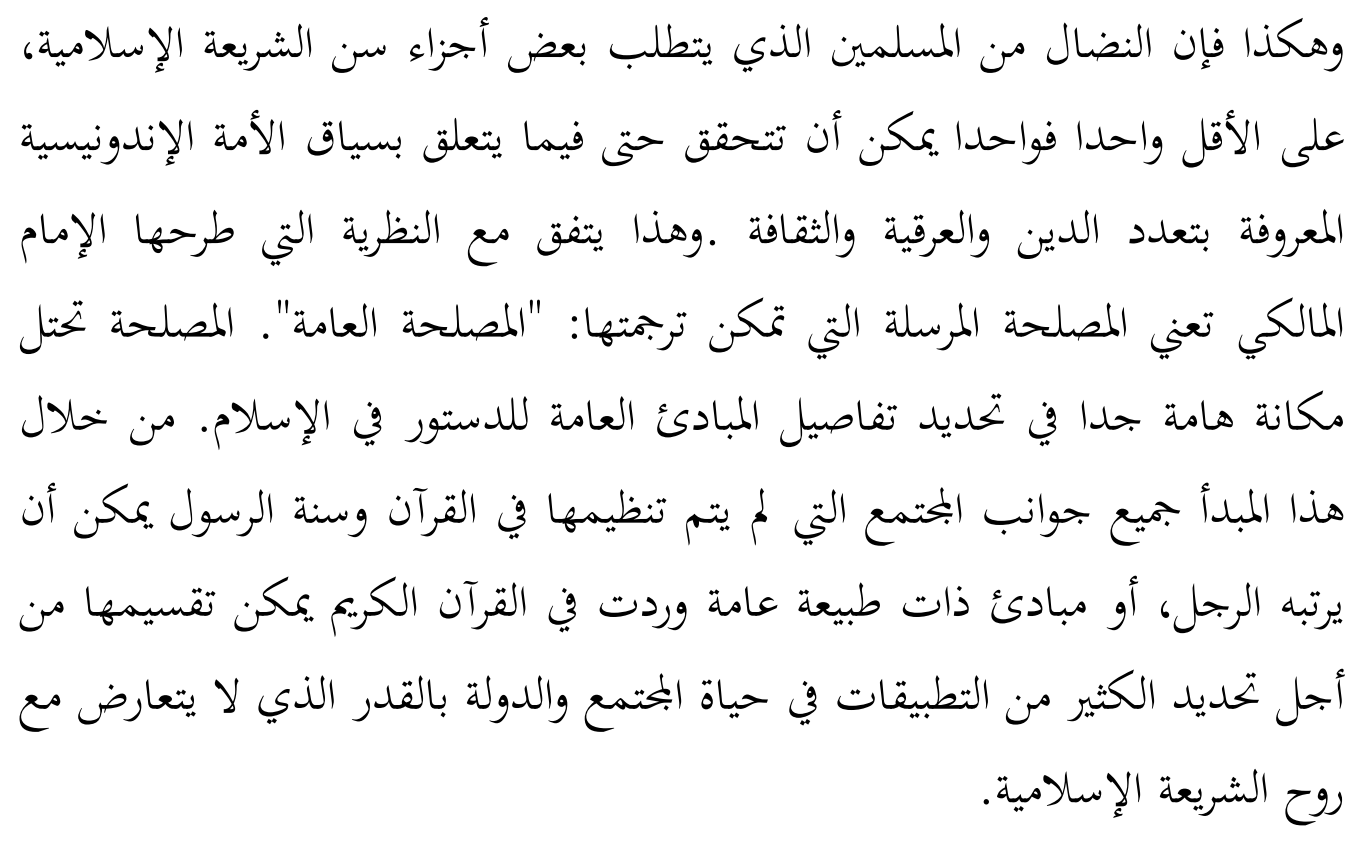

Keywords: Formulasi, Undang-Undang, Negara, Agama.

\section{A. Pendahuluan}

Sebe1um lahirnya UU Perkawinan No. 1 tahun 1974, hukum perkawinan di Indonesia masih bersifat pluralistis, dimana masing-masing golongan dalam masyarakat kita mempunyai hukum perkawinan sendiri yang berbedabeda yaitu: (1) bagi orang-orang Indonesia Asli yang beragama Islam berlaku hukum agama yang telah diresiplir dalam Hukum Adat: (2) bagi orang-orang Indonesia Asli lainnya berlaku Hukum Adat; (3) bagi orang-orang Indonesia Asli yang beragama Kristen berlaku Huwehijks Ordonnantie Christen Indonesia (4) bagi orang-orang Timur Asing Cina dan Warga negara Indonesia keturunan Cina berlaku ketentuan-ketentuan Kitab Undang-undang Hukum Perdata dengan sedikit perubahan; (5) bagi orang-orang Timur Asing lainlainnya dan warganegara Indonesia keturunan Timur Asing lainnya tersebut berlaku Hukum Adat mereka; dan (6) bagi orang-orang Eropa dan warganera Indonesia keturunan Eropa dan Yang dipersamakan dengan mereka berlaku Kitab Undang-undang Hukum Perdata. Kalau golongan-golongan masyarakat 
Indonesia yang bernaung di bawah hukum perkawinan yang beraneka ragam tersebut dibandingkan, maka untuk sebagian besar masyarakat Indonesia beragama Islam, karena itu maka hukum perkawinannya adalah "Hukum Agama Islam" yang telah diresipilir ke dalam Hukum Adat. Aliran fiqih yang paling banyak dianut di Indonesia adalah aliran fiqih mazhab Syafi'i.

Dalam realita kehidupan masyarakat, Hukum Agama Islam yang diterima oleh kebanyakan orang sebagai hukum yang mengatur perkawinan, hanyalah bagian permukaannya saja. Dengan kata lain, sistem hukum perkawinan yang diterima seringkali hanya bentuk-bentuk formalnya saja.Sedangkan jiwa dan asas-asasnya ditinggalkan, diganti dengan adat kebiasaan-kebiasaan dalam masyarakat yang disana sini berbau animisme dan dinamisme. Dalam sistem hukum ini diakui bahwa hak untuk menjatuhkan talak ada pada suami. Suami dapat menjatuhkan talak satu, talak dua, bahkan talak tiga sekaligus dengan ucapan, "Engkau kutalak sebanyak bintang dilangit, atau Engkau kutalak sebanyak pasir di pantai," yang dapat diakukan dimasa saja dan dengan cara bagaimanapun juga bahkan tanpa alasan yang dapat dibenarkan atau tanpa alasan samasekali . Sebaliknya, dalam hal seorang istri yang merasa terpaksa harus bercerai dengan suaminya, tidaklah semudah seperti yang dapat dilakukan seorang suami terhadap istrinya, sehingga sering terjadi seorang istri masih berstatus sebagai istri tetapi kenyataannya tidak merasakan lagi sebagaimana layaknya seorang istri. Hal ini tentu dirasakan tidak adil dan tidak menyenangkan terutama oleh kaum wanita.

Rentetan sejarah kelahiran undang-undang perkawinan yang melalui waktu yang cukup panjang ini bermula dari kesadaran kaum perempuan Islam akan hak-haknya yang merasa dikebiri oleh dominasi pemahaman fikih klasik atau konvensional yang telah mendapat pengakuan hukum. Dan juga tentang pentingnya sebuah keluarga dan perlu diketahui Keluarga merupakan lembaga sosial yang paling berat diterpa oleh arus globalisasi dan kehidupan modern. Dalam era globalisasi, kehidupan masyarakat cenderung materialistis, individualistis, kontrol sosial semakin lemah, hubungan suami istri semakin merenggang, hubungan anak dengan orang tua bergeser, kesakralan keluarga semakin menipis. ${ }^{1}$ Untuk memelihara dan melindungi serta meningkatkan

1 T.O.Ihromi, Bunga Rampai Sosiologi Keluarga, (Jakarta: Yayasan Obor Indonesia, 1999), hal. 284-301. 
kesejahteraan dan kebahagiaan keluarga tersebut disusunlah undang-undang yang mengatur perkawinan dan keluarga. ${ }^{2}$

Telah lama umat Islam di Indonesia ingin memiliki hukum perkawinan tertulis. Keinginan ini sudah muncul pada masa penjajahan Belanda, masa penjajahan Jepang, dan seterusnya sampai pada masa kemerdekaan. Harapan memiliki hukum perkawinan tertulis tersebut baru dapat terwujud pada awal tahun 1974, dengan disahkannya Undang-Undang No: 1 Tahun 1974 tentang Perkawinan.

Pengaturan perkawinan di Indonesia tidak dapat lepas dari keterlibatan tiga pihak/kepentingan, yaitu kepentingan agama, kepentingan negara dan kepentingan perempuan. Dalam konteks, agama dan negara merupakan institusi yang memiliki kepentingan untuk mengadakan pengaturan. Agama sebagai sebuah institusi memiliki kepentingan yang signifikan atas keluarga sebab keluarga sebagai satuan kelompok sosial terkecil memiliki peran penting dalam melakukan sosialisasi nilai-nilai yang ada dalam agama. Sementara itu, negara sebagai institusi modern pun tak bisa mengabaikan keluarga dalam mengatur dan menciptakan tertib warganya meskipun kepentingan negara ini tidak selalu sama dari pemerintahan satu ke pemerintahan yang lain.

Diskusi mengenai agama dan negara masih terus berlanjut di kalangan para ahli. Pada dasarnya yang diperdebatkan adalah perlu tidaknya campur tangan agama dalam urusan kenegaraan. Oleh karenanya, kajian terhadap urgensi beragama dan bernegara menjadi sangat penting. Dari sana kita akan dapat menyimpulkan seberapa besar peranan agama terhadap negara. Juga perlu dimengerti pandangan berbagai ideologi menyangkut masalah ini.

Jika kita lihat hubungan antara agama dan negara kesulitan yang nampak jelas sekali terlihat adalah ketika agama dan negara dilihat sebagai dua entitas yang berbeda. Agama dengan entitas yang transenden tentu sangat berbeda dengan negara sebagai lembaga profan ciptaan manusia. Agama di definisikan sebagai keyakinan pada yang tresenden dengan berbagai laku spiritualis yang mengikutinya harus dikaitkan dengan negara yang merupakan sebuah organisasi kemasyarakatan yang berdiri di atas kesepakatan-kesepakatan dari bermacam-macam golongan untuk bersama-sama bernaung dalam lingkungan organisasi masyarakat yang mereka dirikan guna satu tujuan bersama. Negara

2 Sajtipto Raharjo, Hukum dan Perubahan Sosial, (Bandung: Alumni, 1979), hal. 146-147. 
adalah lembaga ciptaan manusia yang memiliki kekuasaan dan secara absah untuk menggunakan alat represif kepada warganya. Kekuasaan negara ini diperoleh karena negaralah yang diciptakan untuk kebaikan masyarakat dan warganya secara umum. ${ }^{3}$

Agama dan negara memiliki dasar pijakan pada kenyataan yang berbeda. Agama dan negara adalah dua kesatuan sejarah yang berbeda hakikatnya, agama adalah kabar gembira dan peringatan. Sedangkan negara adalah kekuatan pemaksa. Agama mempunyai khatib, juru dakwah dan ulama. Sedangkan negara memiliki birokrasi,pengadilan dan tentara. Agama dapat mempengaruhi jalannya sejarah melalui kesadaran bersama. Negara dapat mempengaruhi sejarah dengan keputusan, kekuasaan dan perang. Agama adalah kekuatan dari dalam dan negara adalah kekuatan dari luar. ${ }^{4}$

Berangkat dari uraian diatas akan semakin jelas bahwa rumitnya hubungan agama dan negara terletak pada masalah definisi dan wilayah jangkauannya. Kesulitan untuk merumuskan hubungan agama yang sakral dengan entitas negara sebagai ciptaan manusia. Permasalahan-permasalahan yang terjadi dari sejak lahirnya undang-undang perkawinan dan juga rumitnya hubungan antara negara dan agama. Jadi, bagaimanakah persingungan hubungan antara negara dan agama dalam formulasi ataupun pembentukan undang-undang No.1 tahun 1974. Sehingga penulis tertarik menulis sebuah karangan ilmiah yang berjudul Formulasi UU No.1 tahun 1974: dalam Persinggungan Antara Agama Dan Agama.

\section{B. Prinsip dan Asas Undang-Undang Nomor 1 Tahun 1974}

Segala peraturan perundang-undangan secara normatifitas pada biasanya disandarkan kepada kaidah atau asas hukum tertentu. Begitu juga dengan Undang-Undang Perkawinan, secara kesuluruhan memiliki asas hukum tersendiri yang tidak dimiliki oleh undang-undang pada umumnya. Asas hukum dalam suatu norma hukum mengandaikan adanya suatu tujuan yang akan diciptakan oleh pembuat hukum atau undang-undang tersebut.

3 Arif Budiman, Teori Negara, Politik, Kekuasaan Dan Ideologi, (Jakata: Gramedia, 2002). hal. 3 .

4 Kuntowijoyo, Identitas Politik Umat Islam, (Bandung: Mizan, 1997), hal. 191. 
Dalam hukum positif adakalanya bahwa asas-asas hukum suatu norma hukum disebutkan secara eksplisit, namun adakalanya tidak disebutkan. Menurut hemat penyusun ketentuan Pasal 30-34 tentang hak dan kewajiban suami isteri dalam UU Nomor 1 Tahun 1974, termasuk norma hukum yang secara eksplisit menyebutkan asas hukumnya.

Mengenai prinsip dan asas hukum, tidak semua ahli hukum menggunakan dua kata tersebut untuk satu maksud atau tujuan. Misalnya tidak menggunakan kata prinsip untuk maksud menjelaskan azas. Namun pada biasanya kebanyakan ahli hukum menggunakan dua kata tersebut secara bergantian untuk menjelaskan azas. ${ }^{5}$ Dalam tulisan ini, asas hukum yang sudah ada dimaksudkan untuk menentukan tujuan ketentuan-ketentuan yang titeliti (Pasal 30-34 Undang-Perkawinan).

Namun secara keseluruhan, di bawah ini dikemukakan asas hukum Undang-Undang Perkawinan menurut C.S.T. Cansil: ${ }^{6}$

1. Tujuan Perkawinan

Tujuan perkawinan adalah untuk membentuk keluarga (rumah tangga) yang bahagia dan kekal berdasarkan Ketuhanan Yang Maha Esa. ${ }^{7}$ Untuk itu suami isteri perlu saling membantu dan melengkapi agar masingmasing dapat mengembangkan kepribadiannya membantu dan mencapai kesejahteraan spiritual dan material. ${ }^{8}$

2. Sahnya Perkawinan

Perkawinan dianggap sah kalau dilakukan menurut hukum masingmasing agama dan kepercayaannya, dan selanjutnya dicatat menurut peraturan perundang-undangan yang berlaku. ${ }^{9}$ Tata cara pencatatan perkawinan sama dengan pencatatan peristiwa-peristiwa penting kehidupan seseorang lainnya. Seperti kelahiran, kematian dan lain-lain.

3. Asas Monogami

Undang-undang perkawinan menganut asas monogami. Hanya apabila dikehendaki oleh yang bersangkutan, karena hukum dan agama

5 Amiur Nuruddin dan Azhari Akmal Tarigan, Hukum Perdata Islam di Indonesia (studi Kritis Perkembangan Hukum Islam dan Fikih, UU No1/1974 Sampai KHI), cet. I (Jakarta: Kencana, 2004), hal. 42-57.

6 C.S.T. Cansil, Pengantar Ilmu Hukum dan Tata Hukum Indonesia, cet. VIII (Jakarta: Balai Pustaka, 1989), hal. 225-227.

7 Undang-Undang Nomor 1 Tahun 1974 Tentang Perkawinan, Pasal 1

8 C.S.T. Cansil, Pengantar Ilmu Hukum dan Tata Hukum Indonesia, ..., hal. 225.

9 Ibid. 
dari yang bersangkutan mengizinkannya, seorang suami dapat beristeri lebih dari seorang isteri. Meskipun hal itu dikehendaki oleh pihak-pihak yang bersangkutan, akan tetapi hanya dapat dilakukan apabila dipenuhi berbagai persyaratan tertentu dan diputuskan oleh pengadilan. ${ }^{10}$

4. Prinsip Perkawinan

Menurut C.S.T. Cansil undang-undang perkawinan menganut prinsip, bahwa calon suami isteri harus masak jiwa raganya untuk dapat melangsungkan perkawinan agar supaya dapat mewujudkan tujuan perkawinan secara baik tanpa berakhir pada perceraian dan mendapat keturunan yang baik dan sehat. Oleh karena itu tidak dibenarkan adanya perkawinan antara calon suami isteri yang masih di bawah umur. Di samping itu menurut Cansil perkawinan berhubungan dengan kependudukan. Menurutnya perkawinan di bawah umur bagi seorang wanita akan mengakibatkan laju kelahiran meningkat. ${ }^{11}$

5. Mempersukar Terjadinya Perceraian.

Berjalan linier dengan tujuan perkawinan, maka undang-undang perkawinan menganut asas untuk mempersukar terjadinya perceraian. Perceraian dibenarkan oleh karena alasan-alasan yang dibenarkan oleh undang-undang serta dilakukan di depan sidang pengadilan. ${ }^{12}$

6. Hak dan Kedudukan Isteri

Hak dan kedudukan isteri adalah seimbang dengan hak dan kedudukan suami baik dalam kehidupan rumah tangga maupun dalam pergaulan masyarakat, sehingga dengan demikian menurut Cansil segala sesuatu dalam keluarga dapat dirundingkan dan diputuskan bersama oleh suami dan isteri. ${ }^{13}$

Berbeda dengan C.S.T. Cansil, Abdul Manan menjelaskan bahwa asasasas perkawinan yang dimuat dalam Undang-undang Perkawinan yaitu ada 6 (enam). Keenam asas tersebut adalah sebagai berikut: ${ }^{14}$

\footnotetext{
10 C.S.T. Cansil, Pengantar Ilmu Hukum dan Tata Hukum Indonesia ,...,hal. 226.

11 Ibid., hal. 227

12 Ibid., hal. 228

13 Ibid., hal. 229

14 Abdul Manan, Aneka Masalah Hukum Perdata Islam di Indonesia, hal. 6.
} 

a. Asas Sukarela. ${ }^{15}$
b. Asas Partisipasi Keluarga. ${ }^{16}$
c. Perceraian Dipersulit ${ }^{17}$
d. Poligami Dibatasi dengan Ketat. ${ }^{18}$
e. Kematangan Calon Mempelai. ${ }^{19}$
f. Memperbaiki Derajat Kaum Wanita. ${ }^{20}$

Sedangkan menurut Yahya Harahap, prinsip-prinsip perkawinan yang terkandung dalam undang-undang nomor 1 tahun 1974 adalah sebagai berikut: ${ }^{21}$

a. Menampung segala kenyataan-kenyataan yang hidup dalam masyarakat bangsa Indonesia dewasa ini.

b. Sesuai dengan tuntutan perkembangan zaman.

c. Tujuan perkawinan adalah membentuk keluarga bahagia yang kekal.

d. Kesadaran akan hukum agama dan keyakinan masing-masing warga Negara bangsa Indonesia yaitu perkawinan harus dilakukan berdasarkan hukum agama dan kepercayaan masing-masing.

e. Undang-undang menganut azas monogami akan tetapi tetap terbuka peluang untuk melakukan poligami selama hukum agamanya mengizinkannya.

f. Perkawinan dan pembentukan keluarga dilakukan oleh pribadi-pribadi yang telah matang jiwa dan raganya.

g. Kedudukan suami isteri dalam kehidupan keluarga adalah seimbang, baik dalam kehidupan rumah tangga maupun dalam pergaulan bermasyarakat.

\section{Persinggungan Antara Agama Dan Negara (Pemerintahan) Dalam Islam}

Sebelum melangkah lebih jauh hendaknya mengetahui terlebih dahulu defenisi tentang agama ada negara sehingga permasalahan dapat tersusun rapi

15 Ibid., hal. 6-7

16 Ibid., hal. 7-8

17 Ibid., hal. 8

18 Ibid., hal. 9-10

19 Ibid., hlm 11

20 Ibid.,hlm11-12

${ }^{21}$ Yahya Harahap, Hukum Perkawinan Nasional (Medan: Zahir Trading, 1975), hal. 10 
tanpa kesimpangsiuran. Agama adalah suatu konsepyang terdiri dari komponen pokok pengaturan hubungan antara manusia dengan Allah (hubungan vertikal) dan antara manusia dengan manusia dalam suatu masyarakat ataupun suatu negara, bahkan mungkin pula antar negara serta antar manusia dengan lingkungan hidupnya (hubungan horizontal). ${ }^{22}$

Sedangkan mengenai negara terdapat Beberapa tokoh yang mendefinisikan pengertian negara sebagai berikut :

1. Roger H. Soultau: negara didefinisikan sebagai agency (alat) atau authority (wewenang) yang mengatur atau mengendalikan persoalan persoalan bersama, atas nama masyarakat.

2. Harold J. Laski mengemukakan menurutnya negara merupakan suatu masyarakat yang diintegrasikan karena mempunyai wewenang yang bersifat memaksa dan yang secara sah lebih agung daripada individu atau manusia yang hidup bekerjasama untuk mencapai terkabulnya keinginan -keinginan mereka bersama.

3. Max Weber mendefinisikan bahwa negara adalah suatu masyarakat yang memiliki monopoli dalam penggunaan kekerasan fisik secara sah dalam suatu wilayah. ${ }^{23}$

Dari beberapa penjelasan di atas, dapat disimpulkan bahwa negara adalah suatu daerah teritorial yang rakyatnya diperintah oleh sejumlah pejabat yang berhak menuntut dari warga negaranya untuk taat pada peraturan perundang - undangan melalui penguasaan monopolistis dari kekuasaan yang sah. ${ }^{24}$

Secara umum terkait masalah agama dan negara pada masa lalu dan masa sekarang ini bukanlah hal yang baru di alami, apalagi dalam dunia Islam. Salah satu hal yang tidak bisa dipungkiri dari Islam ialah pertumbuhan dan perkembangan sistempolitik yang diilhamminya. Geneologi keterkaitan Islam dan politik telah dimulai nabi, terutama sejak periode madinah. ${ }^{25}$

${ }^{22}$ Muhammad Tahir Azhary, Negara Hukum, (Jakarta:Kencana, 2004), hal. 27.

23 Miriam Budiarjo, Dasar - Dasar Ilmu Politik, (Jakarta: Gramedia Pustaka Media, 1987), hal. 39-40

${ }^{24}$ Khairon, dkk, Pendidikan Politik bagi Warganegara, (Yogyakarta: LKIS, 1999), hal. 111114.

25 Menurut Nurcholis Majid kata "madinah" mempunyai arti sebagai peradaban yang dalam istilah yunani kuno bisa disebut dengan polis. Selain itu madinah sering diterjemahkan dengan arti peradaban.namun secara etimologis kata madinah mempunyai arti "kota" dengan pola hidup menetap yang dilawankan dengan kehidupan badawah atau 
Hubungan antara agama dan negara dalam Islam telah diberikan teladannya oleh Nabi saw sendiri setelah hijrah dari mekkah ke madinah. Darinama yang dipilah oleh Nabi saw bagi kota hijrahnya itu menunjukkan rencana nabi dalam rangka mengemban misi dari tuhan, yaitu menciptakan masyarakat berbudidaya tinggi, yang kemudian menghasilkan sautu entitas sosial politik, yaitu sebuah negara. Negara madinah pimpinan nabi itu, adalah model bagi hubungan antara agama dan negara dalam Islam. Dalam pandangan kaum muslim kekuasaan nabi di madinah tidak hanya dibimbing oleh kebijaksanaan manusiawi tapi juga oleh wahyu tuhan. Berpegang teguh pada prinsip tersebut umat Islam pada priode berikutnya menjadikan periode madinah ini sebagai tipe ideal pelaksanaannya karena disanalah terdapat bukti konkrit bagaimana ajaran Islam teraktualisasi dalam sejarah. ${ }^{26}$

Dalam hubungannya agama dengan negara, wacana seputar konsep negara Islam telah melahirkan kontroversi dan polarisasi intelektual dikalangan pemikir politik Islam. Apakah benar, misalnya Rasulullah pernah mendirikan atau menganjurkan negara Islam \{Islamic state), bukan negara suku (clannish state) seperti yang dikemukakan Ali Abdur Raziq. Apakah institusionalisasi Islam dalam bentuk negara merupakan kewajiban syariat ataukah semata-mata kebutuhan rasional seperti yang diteorikan Ibnu Khaldun?

Untuk menjawab persoalan itu, sesuai dengan realitas politik di Indonesia, maka garis besarnya terdapat dua kekuatan dalam memandang Islam dan negara. Pertama, kaum subtansialis, yang memiliki pokok-pokok pandangan (a) bahwa substansi atau kandungan iman dan amal lebih penting daripada bentuknya, (b) pesan-pesan Al-Qur'an dan hadis, yang bersifat abadi dalam esensinya dan universal dalam maknanya, harus ditafsirkan kembali oleh masing-masing generasi kaum muslim sesuai dengan kondisi sosial pada masa mereka, dan (c) mereka menerima struktur pemerintahan yang ada sekarang sebagai bentuk negara Indonesia yang final. Kedua, kaum skripturalis, mereka berpandangan: (a) pesan-pesan agama sebagian besarnya sudah jelas termaktub

masyarakat nomad. Dalam masa modern kata madinah merujuk pada pengertian "civil society" atau masyarakat beradab. Syafiuddin, Negara Islam Menurut Konsep Ibn Khaldun, (Yogyakarta: Gama Media, 2007), hal.132

${ }_{26}$ Mahmoud M. Ayoub, buku the critis of muslim history, akar-akar krisis politik dalam sejarah muslim, terj. Munir A. Mu'in, (bandung: mizan, 2003), hal.11. 
di dalam Al-Qur'an dan hadis, (b) dan hanya perlu diterapkan dalam kehidupan. Karena itu, mereka cenderung lebih berorientasi kepada syariat. ${ }^{27}$

Dari kedua kelompok tersebut jelas bahwa di satu pihak institusi (negara) Islam tidaklah perlu, yang terpenting adalah komitmen penerapan nilai-nilai Islam dalam kehidupan berbangsa, ini dianut oleh kaum subtansialis. Di pihak lain, kelompok skripturalis, yang berpandangan bahwa pesan-pesan agama perlu adanya institusi yang mengaturnya yaitu negara Islam, yang berorientasi pada syariat.

Bila diamati dengan saksama, sesungguhnya kedua kelompok tersebut pada dasarnya memiliki tujuan yang sama, yaitu sama-sama ingin mengartikulasikan pesan agama dengan penuh komitmen dan integral (kaffah). Tujuan yang sama inilah yang hendaknya dibangun dan dikedepankan, berlomba-lomba dalam kebaikan dan kebenaran. Terutama saat ini, dengan menjamurnya partai politik Islam. Menyoal maraknya partai politik Islam, Azyumardi Azra melihat adanya tiga corak kecenderungan baru, yaitu formalistik (menurut aturan secara kaku) artinya melihat Islam sebagaimana aturan yang ada tanpa melihat isi, substantifistik (hakikat, inti) artinya memunculkan Islam dari sisi substansinya bukan sebagai ajaran formalnya, dan sekularistik, artinya melihat agama sebagai ajaran yang terpisah dengan urusan duniawi. Dari tiga kecenderungan yang diajukannya, ia menganjurkan agar partai Islam semestinya memakai pola substantifistik, artinya memunculkan Islam dari sisi substansinya bukan sebagai ajaran formalnya.

Lain halnya dengan Gus Dur, yang dengan tegas menyatakan ada tiga bentuk respons dalam hubungan Islam dan negara (state) yaitu: integratif (bersifat utuh), fakultatif (boleh memilih), dan konfrontatif (adanya pertentangan). ${ }^{28}$ Hubungan integratif, meminjam terminologi Gus Dur, Islam sama sekali menghilangkan kedudukan formalnya dan sama sekali tidak menghubungkan ajaran agama dengan urusan kenegaraan. Hubungan antara kehidupan mereka dan negara ditentukan oleh pola hidup kemasyarakatan yang mereka ikuti.

Yang menarik, ketika Bahtiar Effendy menawarkan hubungan politik yang integratif antara Islam dan negara, bukanlah berarti asal yes terhadap pemerintah

27 Mark R. Woodward, Jalan Baru Islam, Memetakan Paradigma Mutakhir Islam Indonesia, Terj. Chaniago, (Bandung: Mizan, 2004), hal. 285-289.

${ }_{28}$ Abdurrahman Wahid, "Membangun Hubungan Islam Dan Negara," (Jakarta: Kompas, 1998), hal. 6. 
yang berkuasa. Namun ada konsekuensi logis-rasionalnya, yakni: terwakilinya kaum muslim secara proporsional di lembaga-lembaga politik negara. Ini jelas berlainan dengan Gus Dur yang menghilangkan kedudukan Islam formalnya, dan dipertahankannya komitmen nasional bahwa negaraIndonesia bukanlah negara sekuler. Hal ini mengharuskan dipertimbangkan dan diakuinya nilainilai keagamaan dalam proses pembuatan kebijakan. ${ }^{29}$

Jika ini tidak terlaksana dengan baik, maka akan ada benturan dari kedua kelompok besar tersebut yang saling tuding, jegal, merasa benar sendiri, dan seterusnya Niat yang baik teracuni oleh dominasi ego yang berorientasi pada kepentingan materi. Agama kehilangan sifat profetiknya, dari rahmatan lil'alamin (rahmat bagi alam semesta) berubah menjadi mafsadah lil'alamin (kerusakan alam semesta).

Berikut penulis memaparkan contoh mengenai persinggungan antara agama dan negara. Contoh: Cerai talak yang dilakukan di pengadilan agama. Ketentuan mengenai putusnya ikatan perkawinan dan akibat-akibatnya, secara umum diatur di dalam UU No. 1 Tahun 1974 tentang Perkawinan (“UUP”), yang kemudian diatur lebih lanjut di dalam PP No.9 Tahun 1975 tentang Pelaksanaan UU No.1 Tahun 1974 tentang Perkawinan (“PP 9 Tahun 1975”). Dan lebih khusus lagi bagi orang-orang Islam diatur di dalam Kompilasi Hukum Islam (“KHI”).

Menurut Pasal 38 UUP, putusnya ikatan perkawinan dapat disebabkan karena kematian, perceraian, dan keputusan pengadilan. Putusnya ikatan perkawinan yang disebabkan karena perceraian berdasarkan Pasal 114 KHI, dapat terjadi karena talak atau karena gugatan perceraian. ${ }^{30}$

Talak adalah ikrar suami di hadapan sidang Pengadilan Agama (Pasal 117 KHI). Talak yang akan diikrarkan oleh suami kepada isterinya, dilakukan oleh si suami dengan mengajukan permohonan baik lisan maupun tertulis kepada Pengadilan Agama yang mewilayahi tempat tinggal isteri disertai dengan alasan serta meminta agar diadakan sidang untuk keperluan penjatuhan ikrar talak tersebut (Pasal 129 KHI). Di dalam praktik, permohonan yang diajukan

29 Bahtiar Effendy, Islam dan Negara, Transformasi Pemikiran dan Praktik Politik Islam di Indonesia, (Jakarta: Paramadina, 1998).

30 Sudarsono, Hukum Perkawinan Nasional, (Jakarta : PT Rineka Cipta, 1991), hal.116. 
oleh suami tersebut dikenal dengan sebutan permohonan talak, yang mana suami berkedudukan sebagai Pemohon, sedangkan istri sebagai Termohon.

"Talak adalah ikrar suami di hadapan sidang Pengadilan Agama yang menjadi salah satu sebab putusnya perkawinan, dengan cara sebagaimana dimaksud dalam pasal 129, 130, dan 131" (Pasal 117).

Syarat-syarat perceraian termaktub dalam pasal 39 Undang-undang perkawinan terdiri dari 3 ayat, yaitu: ${ }^{31}$

a. Perceraian hanya dapat dilakukan di depan sidang pengadilan setelah pengadilan yang bersangkutan berusaha dan tidak berhasil mendamaikan kedua belah pihak.

b. Untuk melakukan perceraian harus ada cukup alasan, bahwa antara suami istri itu tidak akan hidup rukun sebagai suami istri.

c. Tata cara perceraian di depan sidang pengadilan diatur dalam peraturan perundangan tersendiri.

Putusan perceraian harus didaftarkan pada Pegawai Pencatatan Sipil di tempat perkawinan itu telah dilangsungkan. Mengenai perkawinan yang dilangsungkan di luar negeri, pendaftaran itu harus dilakukan pada Pegawai Pencatatn Sipil di Jakarta. Pendaftaran harus dilakukan dalam waktu enam bulan setelah hari tanggal putusan hakim. Jikalau pendaftaran dalam waktu yang ditentukan olehundang-undang dilalaikan, putusan perceraian kehilangan kekuatannya, yang berarti, menurut undang-undang perkawinan masih tetap berlangsung.

Oleh karenanya, dengan merujuk pada ketentuan tersebut, maka perceraian itu sah apabila dilakukan di depan sidang Pengadilan Agama (setelah Pengadilan Agama tersebut berusaha dan tidak berhasil mendamaikan suami-istri), dengan disertai alasan-alasan perceraian sebagaimana diatur di dalam Pasal 116 KHI tersebut di atas. Lebih lanjut, perceraian antara suami istri dianggap terjadi beserta akibat-akibatnya terhitung sejak jatuhnya putusan Pengadilan Agama yang telah mempunyai kekuatan hukum yang tetap/inkracht van gewijsde (Pasal 146 ayat [2] KHI). Khusus bagi perceraian karena talak, perceraian tersebut terjadi setelah suami mengucapkan ikrar talak di depan sidang Pengadilan Agama.

31 Amir Syarifuddin, Hukum Perkawinan Islam di Indonesia, (Jakarta : Kencana, 2009), hal.227. 
Dari contoh cerai talak diatas dapat diketahui suami harus mengucapkan ikrar talak di pengadilan agama, mengapa harus di pengadilan agama. Karena sudah tercantum didalam kompilasi hukum Islam (KHI) dan juga dalam Undang-undang perkawinan. Dan kompilasi hukum Islam ini juga dijadikan oleh hakim pengadilan agama sebagai pedoman yang harus diikuti dalam menyelesaikan perkara perkawinan, yaitu kompilasi hukum Islam di indonesia yang menyebarluaskannya dilakukan melalui intruksi presiden RI No. 1 tahun 1991 tentang kompilasi hukum Islam. ${ }^{32}$

Jika dilihat dari teori Maslahah Mursalah pembentukan undang-undang itu termasuk dalam kepentingan umum ataupun kemaslahan bersama dengan dibuatnya undang-undang No.1 tahun 1974 kaum wanita di indonesia mendapatkan hak-haknya. Sebagai contohnya pencatatan perkawinan, dengan pencatatan perkawinan wanita di indonesia mendapatkan hak-haknya dalam masa perkawinan ataupun pasca perceraian. Begitu juga dengan ikrar talak di pengadilan agama, dengan adanya ikrar talak di pengadilan agama para wanita tidak akan tertindas dengan pengucapan talak yang semena-mena dari suami diluar pengadilan agama sehingga wanita dapat mempertahankan hakhaknya.

\section{Analisis Terhadap Persinggungan Agama Dan Negara Dalam Pem- buatan UU No. 1 Tahun 1974}

Negara Republik Indonesia, sebagai negara yang berdasarkan Pancasila, di mana sila yang pertama adalah Ketuhanan Yang Maha Esa, maka perkawinan dianggap mempunyai hubungan yang erat sekali dengan agama atau kerohanian, sehingga perkawinan bukan saja mengandung unsur lahir atau jasmani, tetapi unsur batin atau rohani juga mempunyai peranan yang sangat penting. ${ }^{33}$

Jika ditelaah lebih dalam landasan hukum agama dalam melaksanakan sebuah perkawinan merupakan hal yang sangat penting dalam UU No. 1 Tahun 1974, sehingga penentuan boleh tidaknya perkawinan tergantung pada ketentuan agama. Hal ini berarti juga bahwa hukum agama menyatakan

32 Amir syarifuddin, ibid., hal. 21.

33 Rusli, dan R. Tama, 1984, Perkawinan antar agama dan masalahnya. (Bandung: Shantika Dharma), hal. 10 
perkawinan tidak boleh, maka tidak boleh pula menurut hukum negara. Bisa dilihat dengan adanya uu yang lahir dari aturan agama maka agama dan negara terlihat sejalan dan searah.

Berbicara agama dan negara dalam perkawinan, Pengaturan perkawinan di Indonesia tidak dapat lepas dari keterlibatan tiga pihak/kepentingan, yaitu kepentingan agama, kepentingan negara dan kepentingan perempuan. Dalam konteks, agama dan negara merupakan institusi yang memiliki kepentingan untuk mengadakan pengaturan. Agama sebagai sebuah institusi memiliki kepentingan yang signifikan atas keluarga sebab keluarga sebagai satuan kelompok sosial terkecil memiliki peran penting dalam melakukan sosialisasi nilai-nilai yang ada dalam agama. Sementara itu, negara sebagai institusi modern pun tak bisa mengabaikan keluarga dalam mengatur dan menciptakan tertib warganya meskipun kepentingan negara ini tidak selalu sama dari pemerintahan satu ke pemerintahan yang lain.

Masalah pemerintahan di sini tidak terlepas dari Politik. Politik sebagaimana yang dimaksud oleh Van Der Tas yaitu beleid (kebijakan). ${ }^{34}$ Apabila dikaitkan dengan politik hukum, penulis cenderung memahaminya sebagai sebuah bentuk peraturan yang dibuat oleh pemerintah atau lembaga negara yang mempunyai kewenangan dalam membuat peraturan tersebut sebagai sebuah kebijakan yang menentukan arah berkehidupan suatu bangsa. Bentuk nyata yang paling kental dengan hal tersebut adalah diundangkannya sebuah undangundang. Sebagaimana disinggung di awal, bahwa undang-undang perkawinan merupakan salah satu produk perundang-undangan yang disinyalir sangat kuat dipengaruhi oleh aspirasi umat Islam di Indonesia, bahkan perjalanan sejarah telah merekam begitu panjang proses awal sampai lahirnya undangundang perkawinan pada tahun 1974.

Ketika politik hukum diartikan sebagai arah kebijakan negara, dalam hal ini berkaitan dengan diundangkannya UU No. 1 Tahun 1974 tentang Perkawinan, penulis melihat bahwa arah kebijakan yang dimaksud adalah mengakomodir aspirasi umat Islam yang mayoritas memilih faham madzhab syafi'i dan diwujudkan dalam satu bentuk perundang-undangan. Harapannya tentu saja agar nilai-nilai Islam yang sudah sejak lama mewarnai cara berhukumnya

${ }_{34}$ Moh. Mahfud, Politik Hukum di Indonesia Ed. Revisi, (Jakarta: Rajawali Pers, 2014), Cet. 6 , hal. 5 
orang Indonesia, kemudian dapat memiliki ketegasan dan pengakuan dari negara. Dengan begitu perjuangan umat Islam, yang dalam porsi tertentu mengharuskan diberlakukannya hukum Islam, paling tidak satu demi satu dapat terwujud walaupun dengan tetap memperhatikan konteks keIndonsiaan yang dikenal multi agama, etnik dan budaya. Hal ini sesuai dengan teori yang dikemukakan oleh imam maliki yakni al-Mashlahah al-Mursalah ${ }^{35}$ yang dapat diterjemahkan "untuk kepentingan umum". Menurut Imam Malik kepentingan atau kemaslahatan umum salah satu dari sumber-sumber syariah, dengan tiga syarat yaitu: 1). kepentingan umum atau kemaslahatan umum itu bukan yang berkaitan dengan ibadat, 2). Kepentingan atau kemaslahatan umum itu harus selaras dengan jiwa syariah dan tidak boleh bertentangan dengan salah satu sumber syariah itu sendiri, 3). Kepentingan atau kemaslahatan umumitu haruslah merupakan sesuatu yang esensial (diperlukan) dan bukan hal-hal yang bersifat kemewahan. Hal-hal yang diperlukan itu merupakan upaya yang berkaitan dengan lima tujuan hukum Islam sebagaimana yang dirumuskan oleh Syatibi yaitu untuk melindungi agama, kehidupan, akal, keturunan, dan harta.

Al-maslahah menduduki posisi yang sangat penting dalam menentukan rincian prinsip-prinsip umum tentang ketatanegaraan dalam Islam. Karena itu melalui maslahah manusia diberikan kewenangan dan kebebasan untuk memilih dan menentukan sendiri pemerintahan apa yang paling baik bagi mereka.

Dengan demikian dapat disimpulkan bahwa al-maslahah sangat berfungsi dalam kehidupan masyarakat, melalui prinsip ini semua aspek yang kemasyarakatan yang belum diatur dalam Al-Quran dan sunnah Rasul dapat ditata sendiri oleh manusia, atau prinsip-prinsip dasar yang bersifat umum yang ada dalam Al-Quran dapat dirinci lebih lanjut guna menentukan banyak aplikasinya dalam kehidupan masyarakat dan negara sepanjang tidak bertentangan dengan jiwa hukum Islam (syariah).

Adapun yang sudah menjadi peraturan perundang-perundangan negara yang mengatur perkawinan yang diterapkan setelah indonesia merdeka adalah:

35 Maslahah al-murshalah yaitu: pembinaan (penetapan) hukum berdasarkan maslahat (kebaikan, kepentingan) yang tidak ada ketentuannya dalam syara' baik ketentuan secara umum ataupun ketentuan secara khusus. lihat Muhammad Tahir Azhary, Negara Hukum, (Jakarta:Kencana, 2004), hal. 9. 
a. Undang-Undang No. 32 tahun 1954 tentang penetapan berlakukanya undang-undang republik indonesia tanggal 21 november 1946 No. 22 tahun 1946 tentang percetatan nikah, talak dan rujuk di seluruh luar jawa dan madura. Sebagaimana bunyinya undang-undang ini hanya mengatur tata cara pencatatan nikah, talak dan rujuk, tidak materi perkawinan secara menyeluruh. Oleh karena itu tidak dibicarakan dalam bahasan ini.

b. Undang-undang no.1 tahun 1974 tentang perkawinan yang merupakan hukum materil dari perkawinan dengan sedikit menyinggung acaranya.

c. Peraturan Pemerintah No.9 tahun 1975 tentang pelaksanaan undangundang no 1 tahun 1974 tentang perkawinan. PP ini hanya memuat pelaksanaan dari beberapa ketentuan yang terdapat dalam UU No. 1 tahun 1974.

d. Undang-Undang No.7 tahun 1989 tentang peradilan agama sebagaian dari materi undang-undang ini memuat atuaran yang berkenaan dengan atata cara (hukum formil) penyelesaian sengketa perkawinan di pengadilan agama. ${ }^{36}$

Diantara beberapa hukum perundang-undangan tersebut di atas fokus bahasan diarahkan kepada UU No. 1 tahun 1974, karena hukum materiil perkawinan dikeseluruhannya terdapat dalam UU ini. PP No. 9 tahun 1975 hanya sekedar menjelaskan aturan pelaksanaan dari beberapa materi UU No.1 tahun 1974 sedangkan UU No. 7 tahun 1989 mengatur hukum acara atau formil dari perkawinan. Untuk selanjutnya, UU No. 1 tahun 1974 itu dalam bahasan ini disebut UU perkawinan.

UU perkawinan itu disahkan oleh DPR RI dalam sidang paripurna tanggal 22 desember 1973, setelah mengalami sidang-sidang selama tiga bulan. UU perkawinan ini diundangkan sebagai UU No.1 tahun 1974 pada tanggal 2 Januari 1974 (lembaran negara republik indonesia tahun 1974 No.1; tambahan lembaran negara republik indonesia tahun 1974 No. 3019).

36 Amir syarifuddin, hal. 20 
Dari keterangan di atas terlihat sekali hubungan antara agama dan negara dalam UU No.1 tahun 1974 karena dalam keterlibatan antara keduanya sangat terlihat jelas dalam pembuatan uu perkawinan di indonesia. ${ }^{37}$

\section{E. Kesimpulan}

Berdasarkan dari uraian sebelumnya maka dapat ditarik kesimpulan bahwa persinggungan antara agama dan negara dalam formulasi UU No. 1 Tahun 1974 jelas terlihat sekali dalam Pasal 1 dan 2 yang berbunyi: Pasal 1: Perkawinan adalah ikatan lahir batin antara seorang pria dan seorang wanita sebagai suami istri dengan tujuan membentuk keluarga atau rumah tangga yang bahagia dan kekal berdasarkan Ketuhanan Yang Maha Esa. Pasal 2: (1) Perkawinan adalah sah apabila dilakukan menurut hukum masing-masing agama dan kepercayaannya itu. (2) Tiap-tiap perkawinan dicatat menurut peraturan perundang-undangan yang berlaku. Dilahat dari pasal 1 dan 2 tersebut jelas terlihat relevansi antara agama dan negaraJika dilihat dari teori Maslahah Mursalah pembentukanundang-undang itu termasuk dalam kepentinganumum ataupun kemaslahatan bersama dengan dibuatnya undang-undang No.1 tahun 1974 kaum wanita di indonesia mendapatkan hak-haknya. Sebagai contohnya pencatatan perkawinan, dengan pencatatan perkawinan wanita di indonesia mendapatkan hak-haknya dalam masa perkawinan ataupun pasca perceraian. Begitu juga dengan ikrar talak di pengadilan agama, dengan adanya ikrar talak di pengadilan agama para wanita tidak akan tertindas dengan pengucapan talak yang semena-mena dari suami diluar pengadilan agama sehingga wanita dapat mempertahankan hak-haknya.

Dengan formulasi uu No. 1 tahun 1974 juga hubungan antara agama islam khususnya dan negara yang diyakini sebagai dua entitas yang berbeda bersatu dan tidak terpecah belah walaupun didasari oleh dasar hukum dan pijakan yang berbeda.

\section{DAFTAR PUSTAKA}

Al-Mawardiy, Imam, 2000, Hukum Tatanegara dan Kepemimpinan dalam Takaran Islam, Terj. Abdul Hayyie al-Kattani, Kamaluddin Nurdin, 
Jakarta: Gema Insani Press.

Amiur Nuruddin dan Azhari Akmal Tarigan, 2004, Hukum Perdata Islam di Indonesia (studi Kritis Perkembangan Hukum Islam dan Fikih, UU No1/1974 Sampai KHI), cet. I, Jakarta: Kencana.

Ash-Shiddieqy, Hasbi, 1971, Islam dan Politik Bernegara, Jakarta: Bulan Bintang.

Azhary, Muhammad Tahir, 2004, Negara Hukum, Jakarta:Kencana.

Budiarjo, Miriam, 1987, Dasar - Dasar Ilmu Politik, Jakarta: Gramedia Pustaka Medi.

Budiman, Arif, 2002, Teori Negara, Politik, Kekuasaan Dan Ideologi, Jakata: Gramedia.

Cansil, C.S.T, 1989, Pengantar Ilmu Hukum dan Tata Hukum Indonesia, cet. VIII, Jakarta: Balai Pustaka.

Djazuli, A, 2003, Figh Siyasah: Implementasi Kemaslahatan Umat dalam RambuRambu Syari'ah, Jakarta: Prenada Media.

Effendy, Bahtiar, 1998, Islam dan Negara, Transformasi Pemikiran dan Praktik Politik Islam di Indonesia, Jakarta: Paramadina.

Harahap, Yahya, 1975, Hukum Perkawinan Nasional, Medan: Zahir Trading. Ihromi, T.O, 1999, Bunga Rampai Sosiologi Keluarga, Jakarta: yayasan Obor Indonesia.

Khairon, dkk, 1999, Pendidikan Politik bagi Warganegara, Yogyakarta: LKIS. Kuntowijoyo, 1997, Identitas Politik Umat Islam, Bandung: Mizan

Mahfud, Moh, Politik Hukum di Indonesia Ed. Revisi, 2014, Cet. 6, Jakarta: Rajawali Pers.

Mahmoud M.ayoub, 2003, buku the critis of muslim history, akar-akar krisis politik dalam sejarah muslim, terj. Munir A. Mu'in, bandung: mizan.

Nasution, Harun, 1996, Pembaharuan dalam Islam: Sejarah Pemikiran dan Gerakan, Jakarta: Bulan Bintang.

Qodir, Zuly, 2004, Syari'ah Demokratik: Pemberlakuan Syari'ah Islam di Indonesia, Yogyakarta: Pustaka Pelajar.

Raharjo, Sajtipto, 1979, Hukum dan Perubahan Sosial, Bandung: Alumni.

Rusli, dan R. Tama, 1984, Perkawinan antar agama dan masalahnya, Bandung: Shantika Dharma.

Syarifuddin, Amir, 2009, Hukum Perkawinan Islam di Indonesia, Jakarta :

Kencana. 
Wahid, Abdurrahman, 1998, "Membangun Hubungan Islam Dan Negara," Jakarta: Kompas.

Woodward, Mark R, 2004, Jalan Baru Islam, Memetakan Paradigma Mutakhir Islam Indonesia, Terj. Chaniago, Bandung: Mizan.

Sudarsono, 1991, Hukum Perkawinan Nasional, Jakarta : PT Rineka Cipta. 